\title{
POLA DAKWAH MULTIKULTURAL DI KOTA PALU
}

\section{Syamsuri}

Dosen Tetap Jurusan Komunikasi dan Penyiaran Islam FUAD IAIN Palu

\section{Abstract:}

This paper deals with a variety of da'wah in Palu. It is assumed that polarization of people leads to cultural consequences, which are manifested in the form of Islamic organization, such as Alkhairaat, Darul Dakwah wal Irsyad (DDI), and so forth. As a result, suspicion emerges among native people towards rituals carried out by newcomers. This paper is based on multicultural, which emphasizes on universal justice which is inherent in the inividuals regardless of their association to the group. The result shows that there is "mutual understanding" between Muslim preachers from various Islamic organizations. The patterns of da'wah activities in Palu emerged due to the dynamics of economic struggle (mareso masagena), the flexibility of the local culture (nosampesuvu), and the wisdom of community leaders, both formal and informal (tataguna).

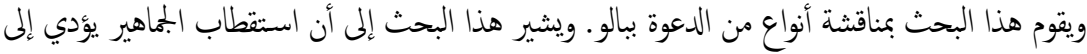

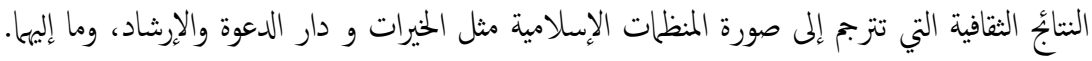

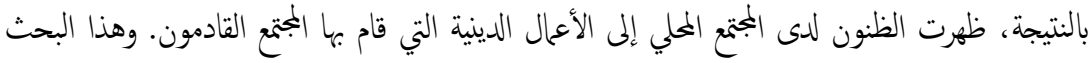

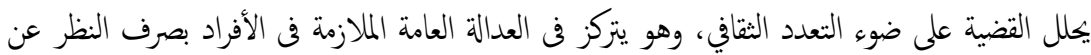

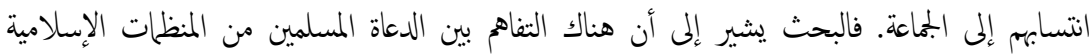

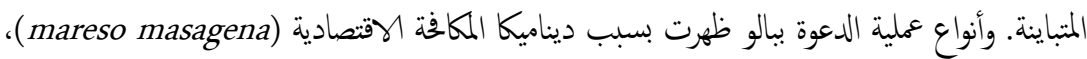

$$
\begin{aligned}
& \text { ومرونة الثقافة المحلية (nosampesuvu) و حكمة رؤساء القوم رسميا أم غير رسمي (tataguna). }
\end{aligned}
$$

Kata Kunci: organisasi, mazhab, kearifan.

\section{Pendahuluan}

Dinamika kehidupan sosial masyarakat kota Palu sering diwarnai bentrok antar suku, antar penganut agama serta antar kelompok pemuda, namun tidak sampai meluas seperti kerusuhan Poso yang berlangsung dari 1998 - 2005. Walaupun demikian, tetap saja riak-riak sosial itu selalu menelan korban harta dan jiwa seperti kasus perkelahian 
antar kampung, penembakan misterius, pemboman tempat-tempat ibadah dan fasilitas umum. Kejadian seperti itu berimbas adanya sikap curiga dan tidak adanya sikap saling menghargai dan menyebabkan lunturnya nilai-nilai toleransi di antara warga.

Kegiatan dakwah yang hanya menampilkan keyakinan keagamaan semata-mata tanpa mengajarkan aspek sosial dari agama itu, selalu mengantarkan umat untuk fanatik terhadap agama yang dianutnya. Fanatisme yang membabi buta selalu melahirkan bentrok sosial, karena tidak adanya kemampuan komunikatif antar agama dan kultural.

Setiap kelompok masyarakat selalu menganggap komunitasnya sebagai golongan yang terbaik dibandingkan dengan kelompok lainnya. Kelompok itu terwujud dalam bentuk kelompok agama atau suku. Berbagai gejolak muncul dan meledak diakibatkan oleh etnosentrisme itu. Ibnu Khaldun menyebut ego kelompok sebagai ta'assub. Solidaritas kelompok disebut așabiyah. Untuk membangun persaudaraan sesama umat manusia disebut al- 'ușbah. ${ }^{1}$

Gagasan Ibnu Khaldun tentang perbedaan-perbedaan pandangan golongan pada setiap kelompok masyarakat, menjadi basis sosiologi masyarakat modern untuk mengurai kemelut yang melanda masyarakat. Seruan toleransi kepada orang-orang selain golongan kelompoknya, menjadi seruan global untuk mewujudkan perdamaian dunia.

Kini, dakwah multikultural terus digelorakan dalam lingkungan sosial, untuk membekali masyarakat beragama untuk dapat hidup berdampingan dengan orang-orang yang di luar kelompoknya. Masyarakat akan terbiasa dalam lingkungan sosial yang bilamana asupan informasi yang harmonis terus dikembangkan sehingga tercipta lingkungan yang kondusif, aman dan nyaman.

Perhatian terhadap karakter dan watak umat beragama telah banyak mengilhami bangsa Indonesia di tengah berbagai keterpurukan.

${ }^{1}$ Ibnu Khaldun, Muqaddimah, (Jakarta: Pustaka: Pustaka Firdaus, 1986), h. 57. 
Keterpurukan multidimensi itu selalu diupayakan segala macam jalan keluarnya. Salah satu jalan keluar itu adalah menanamkan nilai-nilai toleransi dalam pergaulan multikultural. Anggota masyarakat yang memahami nilai-nilai toleransi akan mendukung kehidupan yang baik dalam konteks bermasyarakat.

Lembaga-lembaga dakwah merupakan ajang asupan informasi penanaman nilai-nilai toleransi, kemudian seyogyanya dapat diintegrasikan dalam masyarakat luas. Oleh karena itu, integrasi nilai toleransi seyogyanya terjelma dalam semua lapisan masyarakat. Disinilah peran pemerintah untuk mengoptimalkan keikutsertaan masyarakat dalam membangun peradaban nilai. Pemerintah Kota Palu Provinsi Sulawesi Tengah membuahkan kebijakan holistik dan integratif dengan menyerukan sistem kehidupan multikultural. Kota ini telah berhasil memperlihatkan wajah multikultural dengan tidak terprovokasi oleh insiden-insiden yang terjadi di Kabupaten Poso.

Kini, wacana multikultural disambut oleh para elit agama di Kota Palu dengan melakukan dialog antar pemuka agama. Keharmonisan antar pemeluk agama, jangan lagi dinodai oleh intrik-intrik kekuasaan yang menjadikan agama sebagai basis kekuatan massa. Sebagaimana diketahui bahwa kota yang berada di lintasan garis khatulistiwa ini adalah ibukota Propinsi Sulawesi Tengah yang dipengaruhi oleh dua kutub kultur yaitu "kutub utara ala Eropa" dari Manado dan "kutub selatan ala Timur Tengah" dari Makassar. Pertemuan dua kutub budaya itu melahirkan panorama kultural dengan wujud segmentasi kelompok suku dan agama.

Qasim Mathar mengemukakan bahwa tidak dapat dipungkiri, Indonesia terdiri dari berbagai ras yang berbeda (baik asli, dari luar, maupun campuran), suku bangsa yang berbeda (bangsa Jawa, bangsa Bugis, bangsa Melayu, bangsa Batak, dan sebagainya), berbagai agama yang berbeda, berasal dari banyak negara pribumi (kerajaan Majapahit, kerajaan Sriwijaya, kerajaan Aceh, kerajaan Bugis, kerajaan Makassar, dan lain-lain), dan bercorak-ragam kebudayaan yang berbeda. Karena itu, semua keanekaragaman yang saling berbeda itu harus diterima 
sebagai kenyataan bangsa Indonesia. Kesadaran sebagai bangsa yang multikultural seyogyanya ditumbuhkan terus. ${ }^{2}$

Indonesia menjadi satu bangsa, bukan karena kita berasal dari satu ras yang sama, atau satu suku bangsa yang sama, atau satu agama yang sama, atau berasal dari satu negara pribumi yang sama, atau satu corak kebudayaan yang sama. Bangsa Indonesia tercipta oleh perasaan pengorbanan yang telah kita buat dan alami di masa lampau secara bersama-sama dan secara bersama-sama melalui serta mengalami masa sekarang dengan kesepakatan-kesepakatan yang kita buat secara bersamasama; dan selanjutnya secara bersama-sama pula kita mau melewati masa depan untuk terus hidup bersama-sama. Semangat multikultural hendaknya dibangun pada benak setiap warga negara Indonesia.

Dari data pusat statistik, jumlah penduduk menurut agama yang dianut di Sulawesi Tengah 2009 adalah Islam (77,06\%), Kristen (17,06\%), Katholik (1,42\%), Hindu (1,04\%), Budha $(0,42 \%) .{ }^{3}$ Data statistik ini menunjukkan keragaman masyarakat Sulawesi Tengah dalam konteks keberagamaan. Palu sebagai ibukota Provinsi Sulawesi Tengah menjadi cermin persentese dari kemajemukan itu. Mobilitas lintas kehidupan menjadikan Kota Palu sebagai area medan magnet kehidupan toleransi. Kota Palu menjadi benteng yang kokoh untuk menampilkan corak, rasa, dan citra multikultural.

Sedangkan suku yang mendiami Kota Palu adalah, Kaili sebagai suku asli, Bugis sebagai pendatang dari Sulawesi Selatan. Selanjutnya ada Arab, Bali, Flores, Minangkabau, Jawa, Manado, Gorontalo, Ternate, Papua, Sunda, Betawi dan Cina. Keragaman suku ini sangat dimaknai penduduk asli sebagai arti keterbukaan dalam kehidupan sosial.

Manusia antar budaya bukanlah suatu status (being) melainkan suatu proses menjadi (becoming). Ia bukanlah suatu keadaan,

2 Qasim Mathar, "Demokrasi dan Kebebasan Beragama Pada Masyarakat Multikultural", dalam Syihabuddin (ed.), Memelihara Kerukunan Melalui Pendidikan Multikultural, (Jakarta: Kementerian Koordinator Kesejahteraan Rakyat, 2009), h. 11.

${ }^{3}$ Biro Pusat Statistik Provinsi Sulawesi Tengah, 2013. 


\section{$\Delta \underline{L}-$ กI}

melainkan suatu pencarian. Dengan usaha yang sungguh-sungguh, manusia akan sampai pada tingkat manusia antar budaya yang kita harapkan, yang membuat hidup lebih bermakna. Jika asumsi ini dapat diterima maka salah satu usaha untuk menanggulangi konflik adalah dengan mendidik manusia untuk menjadi pribadi yang menghargai keanekaragaman budaya. ${ }^{4}$

Melalui pola dakwah multikultural kita dapat menciptakan generasi yang tidak terkungkung oleh pandangan kesukuan dan ideologi agama tertentu. Pola dakwah yang ditampilkan oleh Nabi Muhammad SAW (selanjutnya disebut Nabi), tidak pernah menggusur dan menghukum orang-orang yang tidak mau mengikuti ajakan dakwah, bahkan Nabi mendoakan mereka untuk suatu saat dan kelak nanti dapat tercerahkan dan memeluk agama Islam.

Potensi kedinamikaan dan kebhinnekaan itulah harus terus dipertahankan dari generasi ke generasi sehingga tercipta negara kesatuan Republik Indonesia yang "gemah ripah loh jinawi toto tentrom kerto raharjo" yang ditopang oleh suasana Kota Palu yang memegang prinsip "rasa risi roso" (saling memahami, saling membantu dan saling menguatkan).

Berdasarkan latar belakang masalah ini, penulis tertarik melakukan penelitian dengan judul, "POLA DAKWAH MULTIKULTURAL DI KOTA PALU (Studi Perbedaan Mazhab Organisasi Massa Islam).

\section{Rumusan Masalah}

Adapun rumusan masalah dalam penelitian ini, adalah:

1. Bagaimana muballig di Kota Palu memahami perbedaan mazhab?

2. Bagaimana upaya penyampaian dakwah khilafiyah di Kota Palu?

3. Bagaimana dinamika dakwah multikultural di Kota Palu?

${ }^{4}$ Deddy Mulyana, Komunikasi Antar Budaya, (Bandung: Remaja Rosdakarya, 2000), h. 237. 


\section{Siginifikansi Penelitian}

Penelitian ini memiliki signifikansi untuk pengembangan ilmu dakwah. Ilmu dakwah diklasifikasikan sebagai bagian dari kajian studi Islam yang memiliki dimensi-dimensi elementer kebakuan ilmiah. Penelitian dilakukan terus menerus untuk menghindari kebekuan ilmiah. Ada pandangan yang menyebutkan bahwa ilmu dakwah bersumber langsung dari wahyu Allah SWT yang langsung laksanakan oleh Nabi Muhammad SAW ${ }^{5}$, kemudian dilanjutkan oleh umat Islam ${ }^{6}$ hingga akhir zaman.

Hal ihwal tentang ilmu dakwah, memiliki dua elemen pengkajian, yaitu petunjuk wahyu Allah SWT dan realitas sosial. Dorongan lahirnya ilmu dakwah bersumber dari Alqurān yang menyebut kata da'a dengan segala perubahan wazan (struktur kata dalam bahasa Arab), yaitu da'a, yad'ū da'watan yang tertera dalam Alqurān sebanyak 289 kali. ${ }^{7}$ Dari jumlah ini, sebanyak 273 kali, dakwah berarti doa dan hanya 16 kali, dakwah berarti mengajak, menyeru dan memanggil. Ajakan inipun bermakna ajakan Allah SWT masuk surga dan ajakan syaitan masuk neraka.

${ }^{5}$ Berbagai pandangan tentang permulaan dakwah, Harfeni menyebutkan dakwah dimulai dari Nabi Nuh AS, yang memanggil manusia di zamannya untuk beriman kepada Allah SWT, namun ada beberapa orang termasuk istri dan anaknya yang membangkang. Umat Nabi Nuh AS ditimpa musibah banjir. Setelah itu, dakwah Nabi Musa AS, kemudian dakwah Nabi Isa AS, hingga dakwah Nabi Muhammad SAW. Harfeni. Sejarah Dakwah. (Jakarta: Rajawali Pers, 2005), h. 3. Dalam penelitian ini, dakwah yang dimulai dari Nabi Muhammad SAW (selanjutnya disebut Nabi), khususnya di Indonesia, dakwah sudah dibakukan sebagai kegiatan menyampaikan ajaran Islam kepada umat Islam, karena kalau disebutkan dakwah sebagai seruan kepada manusia, dapat menimbulkan pertentangan dengan agama lain.

${ }^{6}$ Kategorisasi keumuman berdakwah menimbulkan pandangan dasar hukum dakwah yaitu, fardhu ain dan fardhu kifayah. Sebagai fardhu ain, setiap umat Islam berwajib berdakwah minimal pada dirinya sendiri. Sedangkan sebagai fardhu kifayah, hanya orang tentu yang memiliki kemampuan keilmuan agama Islam yang wajib berdakwah.

${ }^{7}$ Muhammad Fuad Abd al-Baqi, Mu'jam al-Mufahraz Li Alfaz al-Qur'an alKariim. Beirut: Dar al-Fikr, 1985), h. 97. 


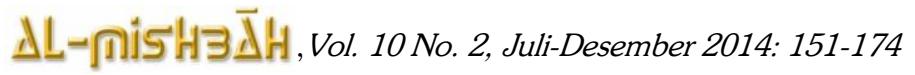

Kajian penelitian pola dakwah multikultural di Kota Palu akan meneguhkan adanya relasi sosial, seperti yang dipraktekkan oleh Nabi dalam menghadapi kemajemukan masyarakat di Madinah. Pola dakwah di Kota Palu akan menambah referensi keilmuan dakwah yang tergali dari realitas sosial. Masyarakat dalam segala kenamikaannya selalu menampilkan ketahanan hidup dalam mengamalkan agama dan ideologinya.

\section{Kerangka Teori}

\section{Dakwah Multikultural}

Dakwah pada hakikatnya hadir dalam sajian sosial yang berbasis multukultural. Dakwah sejak Nabi di Makkah sudah menjumpai orangorang yang berbagai latar belakang agama dan suku. Tantangan dakwah yang semakin berat di Kota Makkah, membuat Nabi berhijrah ke Madinah. Di kota ini, Nabi sukses berdakwah di tengah-tengah keragaman masyarakat Madinah. Umat Islam bersama Nabi hidup berdampingan dengan penganut agama Nasrani dan Yahudi.

Kemampuan manajerial Nabi, membuat pengaruh Islam membahana seantero jagad jazirah Arab, membuat Islam sebagai kekuatan adidaya mengungguli Emperium Romawi dan Persia. Pergulatan umat Islam dalam bersentuhan dengan berbagai latar belakang agama dan kebudayaan, membuat Islam menampilkan peradaban di bidang sains dan teknologi.

Ketika Islam masuk di Nusantara, Islam berhadapan dengan sistem sosial yang berbeda dengan jazirah Arab. Islam di Indonesia berhadap dengan kebudayaan Hindu dan Buddha. Kedua agama ini menganut asas pengolahan jiwa dan nurani (budi), sehingga Islam yang kaya dengan refernsi aktualisasi nilia, sehingga tasawuf dan tarekat dimunculkan oleh para muballig. Proses akulturasi Islam yang sangat santun dan cantik, tanpa perang dan pergulatan, membuat Islam Islam Nusantara memiliki "kekhasan" di banding dengan negara-negara lain.

Seiring masuknya penjajah dari Eropa, menyusul pula misi zending Nasrani di Nusantara. Islam yang sudah terakulturasi dalam 
kehidupan multidimensi, tidak pernah melakukan penentangan dengan cara yang demonstratif. "Bagimu agamamu dan bagiku agamaku" (Surah al-Ikhlas ayat 6) terus diamalkan secara konsisten oleh umat Islam. Ujian multikultural bangsa Indonesia terjadi pada masa penjajahan. Keuletan umat Islam dalam mengarungi "samudera" sosial Nusantara bagai "Pinisi" kehidupan dalam meniti ombak dan gelombang prahara kolonial.

\section{Teori Konstruksi Sosial}

Konstruksi sosial (social construction) merupakan sebuah teori sosiologi kontemporer yang dicetuskan oleh Peter L. Berger dan Thomas Luckman dalam Bungin (2001). ${ }^{8}$ Menurut kedua orang ahli sosiologi ini, teori konstruksi sosial dimaksudkan sebagai satu kajian teoritis dan sistematis mengenai sosiologi pengetahuan (penalaran teoritis dan sistematis), dan bukan suatu tinjauan historis mengenai perkembangan disiplin ilmu. ${ }^{9}$ Oleh karena itu, teori ini tidak memfokuskan pada ha-hal semacam tinjauan tokoh, pengaruh dan sejenisnya, tetapi lebih menekankan pada tindakan manusia sebagai aktor yang kreatif dan realitas sosialnya.

Dalam menjelaskan paradigma konstruktivis, realitas sosial yang diciptakan oleh individu. Individu adalah manusia bebas yang melakukan hubungan antara manusia yang satu dengan yang lain. Individu menjadi penentu dalam dunia sosial yang dikonstruksi berdasarkan kehendaknya. Individu bukanlah korban fakta sosial, namun sebagai mesin produksi sekaligus reproduksi yang kreatif dalam mengonstruksi dunia sosialnya. ${ }^{10}$

Teori ini berpendirian untuk lebih menghadirkan konsep dasar tentang sosiologi pengetahuan yang memperoleh realitas sui generis (istilah kuncu Durkheim). Realitas merupakan hasil ciptaan manusia

\footnotetext{
${ }^{8}$ Burhan Bungin, Konstruksi Sosial Media, (Jakarta: Media Pers, 2001), h. 4

${ }^{9}$ Ibid.

${ }^{10}$ Ibid.
} 
kreatif melalui kekuatan konstruksi sosial terhadap dunia sosial di sekelilingnya. Max Weber melihat realitas sosial sebagai perilaku sosial yang memiliki makna subjektif. Oleh karena itu, perilaku memiliki tujuan dan motivasi. Berger dan Luckmann mengatakan bahwa realitas sosial terdiri dari tiga macam, yaitu realitas objektif, simbolik, dan subjektif. Realitas objektif terbentuk dari pengalaman di dunia objektif yang berada di luar diri individu dan realitas itu dianggap sebagai suatu kenyataan. Realitas simbolik merupakan ekspresi simbolik dari realitas objektif dalam berbagai bentuk. Sedangkan realitas subjektif adalah realitas yang terbentuk sebagai proses penyerapan kembali realitas objektif dan simbolik ke dalam individu melalui proses internalisasi. ${ }^{11}$

\section{Teori Multikultural}

Jika budaya suatu bangsa memilki banyak segi, nilai-nilai dan lain-lain; budaya itu dapat disebut pluralisme budaya (cultural pluralism). Teori ini dikembangkan oleh Horace Kallen yang menggambarkan pluralisme budaya itu adalah menghargai berbagai tingkat perbedaan, tapi masih dalam batas-batas menjaga persatuan nasional. ${ }^{12}$

Pandangan multikultural merupakan tuntunan yang komprehensif mengenai keadilan dalam negara multikultural akan memasukkan hak-hak universal yang melekat pada individu tanpa melihat keanggotaannya pada suatu kelompok, dan hak-hak tertentu yang membedakan kelompok atau 'status khusus' untuk kebudayaan minoritas. ${ }^{13}$

Multikultural terdiri dari dua kata yaitu multi dan kultural. Multi berarti banyak, beragam, bermacam-macam dan kata kultur atau budaya berasal dari bahasa Latin Colere yang berarti merawat,

\section{${ }^{11} \mathrm{Ibid}$.}

12 Sutarno, Pendidikan Multikultural, (Jakarta: Departemen Pendidikan Nasional, 2008), h. 2-3.

${ }^{13}$ Kymlicka, Kewargaan Multikultural. (Jakarta. Pustaka LP3ES, 2002), h. 8. 
memelihara, dan menjaga. ${ }^{14}$ Multikultural adalah istilah yang digunakan untuk menjelaskan pandangan seseorang tentang ragam kehidupan di dunia, ataupun kebijakan kebudayaan yang menekankan tentang penerimaan terhadap realitas keragaman, dan berbagai macam budaya (multikultural) yang ada dalam kehidupan masyarakat menyangkut nilainilai, sistem, budaya, kebiasaan, dan politik yang mereka anut. ${ }^{15}$

\section{Metode Penelitian}

Penelitian ini menggunakan metode kualitatif dengan kajian teoritik komunikasi kelompok. Sebagai penelitian dengan pendekatan interpretatif, alat analisisnya adalah etnografi. Penelitian menekankan pada pemahaman mengenai masalah-masalah dalam kehidupan sosial berdasarkan kondisi realitas atau natural setting yang realistis, kompleks dan rinci. Pendekatan etnografi dimaksudkan untuk mengungkapkan bahwa realitas tidak berdiri sendiri tetapi dipengaruhi oleh ideologi kesukuan atau kelompok.

Lokasi penelitian adalah Kota Palu, yang dikenal dengan tingkat heteroginitas kependudukan dibarengi mobilitas penduduk yang sangat dinamis. Kekentalan kegiatan dakwah dipicu oleh militansi kerusuhan Poso dan isu-isu kekerasan atas nama agama. Penelitian tentang pola dakwah multikultural ditinjau dari hadirnya perbedaan mazhab antar organisasi massa Islam berlangsung selama dari bulan Maret 2013 sampai Desember 2013.

Informan dalam penelitian ini adalah tokoh-tokoh agama dan pemimpin kelompok yang berbasis keagamaan. Kuswarno mengemukakan beberapa kriteria yang dapat dijadikan acuan dalam memilih informan dalam penelitian etnografi, yaitu:

1. Informan harus mengalami langsung situasi atau kejadian yang berkaitan dengan topik penelitian.

h. 17

${ }^{14}$ F. Josef Eilers, Berkomunikasi Antara Budaya, (Flores: Nusa Indah, 1995),

${ }^{15}$ www.wikipedia.com, 28 Mei 2014 
2. Informan mampu menggambarkan kembali gejala kelompok yang telah dialaminya, terutama dalam sifat alamiah dan maknanya. Hasilnya akan diperoleh data yang alami dan reflektif menggambarkan keadaan yang sesungguhnya.

3. Bersedia untuk terlibat dalam kegiatan penelitian yang mungkin membutuhkan waktu yang lama.

4. Bersedia untuk diwawancara dan direkam aktvitasnya selama wawancara atau selama penelitian berlangsung.

5. Memberikan persetujuan untuk mempublikasikan hasil penelitian. ${ }^{16}$

Ada dua jenis data yang digunakan dalam penelitian ini, yaitu data primer dan data sekunder. Data primer adalah data yang diperoleh langsung dari informan dengan menggunakan metode observasi dan wawancara. Adapun data sekunder adalah data yang diperoleh dari upaya studi pustaka terhadap dokumen-dokumen tertulis yang ada dan relevan dengan penelitian ini yang menggunakan metode dokumentasi.

\section{Islam dan Multikultural di Kota Palu}

\section{Sejarah Singkat Kota Palu}

Kota Palu sebagai ibukota Provinsi Sulawesi Tengah pada masa pemerintahan kolonial Belanda merupakan sub wilayah (onder afdeling) dari Donggala. Sebagai onder afedeling Palu terdiri atas landscap Palu yang meliputi Distrik Palu Timur, Distrik Palu Tengah, dan Distrik Palu Barat. Selain landscap Palu, wilayah onder afdeling juga meliputi landscap Kulawi dan landscap Sigi Dolo.

Cikal bakal Kota Palu terbentuk atas terjadinya pengalihan pusat pemerintahan Kabupaten Donggala dari Banawa ke Palu, pada tahun 1950. Bekas Kantor Bupati Donggala adalah yang kini menjadi Kampus Universitas Alkhairaat Jl. Diponegoro No. 12 Palu. Pengalihan tersebut diprkarsai oleh Ketua Yayasan Alkhairaat yang juga Bendahara Dewan

${ }^{16}$ Engkus Kuswarno, Metode Penelitian Fenomenologi, (Bandung: Widya Pajajaran, 2008), h. 61. 
Pimpinan Pusat (DPP) Partai Golkar dengan Bupati Donggala, H. Nabi Bidja pada tahun 2001. Sedangkan Rumah Jabatan Bupati Donggala adalah yang kini menjadi Wisma Donggala Jl. Diponegoro No. 13 Palu.

Berdasarkan Undang-Undang Nomor 44 Tahun 1950, wilayah Sulawesi Tengah berkedudukan di Poso dan Palu menjadi tempat kedudukan kepala pemerintahan negeri setingkat wedana. Kemudian kota teluk ini menjadi ibukota Keresidenan pada tahun 1957. Setelah pembentukan Provinsi Daerah Tingkat I Sulawesi Tengah, Palu menjadi wilayah administratif berdasarkan Peraturan Pemerintah Nomor 18 Tahun 1978.

Perkembangan Palu terjadi pasca penetapan sebagai Kotamadya pada tahun 1994 sekaligus ibukota Provinsi Sulawesi Tengah. Kota ini terletak sekitar $1.650 \mathrm{~km}$ sebelah timur laut Jakarta. Luas wilayah 395,1 kmĀ. Penduduknya berjumlah 342.754 jiwa. Kota Palu berada di Teluk Palu, sebelah barat Selat Makassar. Asal usul nama Kota Palu adalah kata Topalu'e yang artinya tanah yang terangkat karena daerah ini awalnya lautan. Peristiwa gempa bumi lalu terjadi pergeseran lempeng (Sesar Palu Koro) sehingga daerah yang tadinya lautan, terangkat dan membentuk daratan lembah yang sekarang menjadi Kota Palu. Daerah otonom ini dibagi kepada 8 kecamatan dan 45 kelurahan. Kecamatan-kecamatan tersebut adalah Palu Barat, Ulujadi, Palu Selatan, Tatanga, Palu Timur, Mantikulore, Palu Utara, dan Tawaeli.

Pemerintahan pada masa lalu, sudah dikenal struktur birokrasi kerajaan yang bernama Kagau. Raja disebut Magau, didampingi oleh Raja Muda yang disebut Madika Magau. Dalam penyelenggaraan pemerintahan, Magau dibantu oleh Libu Nu Maradika (Dewan Pemerintahan Kerajaan) yang terdiri atas: Madika Matua (Ketua Dewan Kerajaan/Perdana Menteri) bersama Punggawa (Pengawas Pelaksana Adat/Hubungan Dalam Negeri), Galara (Hakim Adat), Pabisara (Juru Bicara), Tadulako (Urusan Keamanan/Panglima Perang), dan Sabannara (Bendahara dan Urusan Pelabuhan).

Di samping Libu Nu Maradika, ada Libu Nto Dea (Dewan Permusyawaratan Rakyat) yang beranggotakan Pitunggota Ngata 


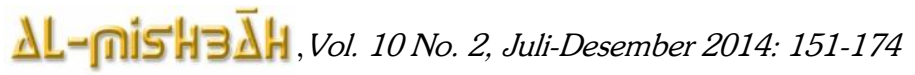

(Dewan yang mewakili Tujuh Penjuru Wilayah). Bentuk Kota Pitunggota atau Kota Patanggota berdasarkan luas wilayah kerajaan yang memiliki banyaknya perwakilan Soki (kampung). Ketua Kota Pitunggota atau Kota Patanggota disebut Baligau.

Suku Kaili adalah penduduk asli Kota Palu. Strata sosial masyarakat Kaili mengenal beberapa tingkatan yaitu Madika/ Maradika (golongan keturunan raja atau bangsawan), Totua Nungata (golongan tokoh-tokoh masyarakat), Todea (golongan masyarakat biasa), dan Batua (golongan hamba/budak).

Pada zaman sebelum penjajahan Belanda, daerah yang didiami suku Kaili memiliki raja yang masing-masing menguasai daerah kekuasaan, seperti Banawa, Palu, Tavaeli, Parigi, Sigi, dan Kulavi. Rajaraja tersebut mempunyai pertalian kekeluargaan yang diperkuat oleh tali perkawinan antara satu dengan yang lainnya, dengan maksud untuk mencegah pertempuran antara satu dengan lainnya serta mempererat kekerabatan.

Suku Kaili adalah suku bangsa Indonesia yang secara turun temurun mendiami sebagian besar dari Provinsi Sulawesi Tengah, khususnya wilayah Kabupaten Donggala, Kabupaten Sigi, dan Kota Palu. Kawasan ini berada di lembah antara Gunung Gawalise, Gunung Nokilalaki, Kulawi, dan Gunung Raranggonau. Mereka juga menghuni wilayah pantai timur Sulawesi Tengah, meliputi Kabupaten Parigi Moutong, Kabupaten Tojo Una Una dan Kabupaten Poso. Masyarakat suku Kaili mendiami kampung/desa di Teluk Tomini yaitu Tinombo, Moutong, Parigi Sausu, Ampana, Tojo dan Una Una. Sedang di Kabupaten Poso mereka mendiami daerah Mapane, Uekuli dan pesisir Pantai Poso.

Sejarah perkembangan pembangunan Kota Palu tidak lepas dari peran sosok pemimpin daerah yang saat ini tercatat telah tujuh kali pergantian kepemipinan kepala daerah. Adapun urutan kepala daerah di Kota Palu, yaitu:

1. Drs H. Kiesman Abdullah, Walikota Administratif, 27 September 1978 - 30 Oktober 1986. 
2. Drs. Syahbuddin Labadjo, Walikota Administratif, 30 Oktober 1986 - 18 April 1994.

3. Rully A. Lamadjido, Walikota Administratif, 18 April 1994 - 12 Oktober 2000.

4. H. Baso Lamakarate dan Suardin Suaebo, Walikota dan Wakil Walikota Palu, 12 Oktober 2000 - 24 Mei 2004.

5. H. Suardin Suaebo, Walikota Palu, 24 Mei 2004 - 12 Oktober 2005. Kepala Daerah ini melanjutkan masa bhakti satu periode, karena H. Baso Lamakarate meninggal dunia pada 24 Mei 2004.

6. H. Rusdy Mastura dan H. Suardin Suaebo, Walikota dan Wakil Walikota Palu, 12 Oktober 2005 - 12 Oktober 2010.

7. H. Rusdy Mastura dan H. Mulhanan Tombolotutu, Walikota dan Wakil Walikota Palu, 12 Oktober 2010 - 12 Oktober 2015.

Pada 27 September 2014, Kota Palu merayakan Hari Ulang Tahun (HUT) ke 36, ditandai dengan perkembangan yang sangat pesat. Deretan supermarket berdiri di kota ini dengan segala ativitas bisnisnya, yaitu Matahari, Carrefour, dan Ramayana. Hotel-hotel berbintang juga mengisi kilau gemerlap Teluk Palu, yaitu Swissbell Hotel, Hotel Grand Duta, Mercure Hotel, Hotel Santika, Hotel Sutan Raja, dan Hotel Palu Golden. Denyut nadi pembangunan niaga dikomplekskan oleh kehadiran Kawasan Ekonomi Khusus (KEK) Palu.

\section{Palu Kota Religi}

Penyematan nama Bandar Udara Mutiara SIS Aldjufri di Kota Palu menandakan bahwa penetrasi politik muballig mampu memengaruhi jantung kekuasaan di Kota Palu. Besarnya massa Alkhairaat mendorong Walikota Palu mengusulkan penambahan nama pendiri Perguruan Islam Alkhairaat pada Bandar Udara di ibukota Provinsi Sulawesi Tengah ini. Akumulasi massa terkumpul dalam acara Haul Guru Tua setiap tahun setelah lebaran Idul Fitri, yakni pada setiap tanggal 12 Syawal penanggalan Hijriyah.

Sayyid Idrus bin Salim (SIS) Aldjufri adalah muballig dari Hadramaut,Yaman yang mendirikan Perguruan Islam Alkhairaat di Kota 
Palu. Organisasi ini mengembangkan pendidikan dan dakwah di kawasan timur Indonesia. Sehubungan dengan berdirinya cabangcabang organisasi di berbagai daerah, dibentuklah Pengurus Besar Alkhairaat. Ini artinya bahwa Alkhairaat sudah menjadi organisasi massa (ormas). SIS Aldjufri berhasil melakukan transformasi sosial pada proses pengembangan dakwah di Kota Palu yang merambah pulau Maluku, Sofifi, Ternate, Papua, dan Kalimantan.

Kini Alkhairaat menjadi primadona politisi dari berbagai macam partai untuk mendekatinya, karena dianggap memiliki pengaruh potensial elektabilitas. Calon presiden, calon wakil presiden, dan politisi nasional lainnya selalu mengagendakan untuk bertemu dengan pimpinan Alkhairaat, ketika mengunjungi Kota Palu. Pada 11 Juni 2014 misalnya, Calon Wakil Presiden H.M. Jusuf Kalla mengunjungi dan bertemu dengan Ketua Utama Alkhairaat, Sayyid Saggaf Muhammad Aldjufri. Setiap menjelang even politik, seperti Pemilihan Umum Legislatif, Pemilihan Presiden, dan Pemilihan Kepala Daerah, pimpinan Alkhairaat selalu didatangi untuk minta restu dalam rangka peluang keterpilihan seorang kandidat.

Wilayah markas Perguruan Alkhairaat ditetapkan sebagai Kawasan Kota Religi oleh Walikota Palu, H. Rusdy Mastura pada tahun 2008. Kawasan ini meliputi wilayah Palu Barat, dengan konsentrasi Kelurahan Baru, Kelurahan Kamonji, Kelurahan Siranindi, Kelurahan Boyaoge, dan Kelurahan Lere. Prakarsa ini tidak terlepas dari jejak dakwah Pendiri Utama Alkhairaat, Sayyid Idrus bin Salim Aldjufri. Perguruan Alkhairaat di kawasan ini terdiri atas unit perkantoran, unit pendidikan, dan unit usaha.

Unit perkantoran Alkhairaat, yaitu:

1. Kantor Pengurus Pusat Alkhairaat

2. Kantor Yayasan Alkhairaat

3. Kantor Badan Pengurus Harian Yayasan Alkhairaat

4. Kantor Pengurus Pusat Wanita Islam Alkhairaat (WIA)

5. Kantor Pengurus Pusat Himpunan Pemuda Alkhairaat (HPA)

6. Kantor Pengurus Pusat Banaat Alkhairaat 
7. Kantor Pengurus Pusat Ikatan Alumni Alkhairaat (IKAAL) Unit pendidikan Alkhairaat, yaitu:

1. Universitas Alkhaairaat

2. Madrasah Aliyah Alkhairaat

3. Sekolah Menengah Kejuruan (SMK) Alkhairaat

4. Madrasah Tsanawiyah (MTs) Alkhairaat

5. Sekolah Menengah Pertama (SMP) Alkhairaat

6. Sekolah Dasar (SD) Alkhairaat

7. Taman Kanak-Kanak (TK) Alkhairaat

Unit usaha Alkhairaat, yaitu:

1. Rumah Sakit Alkhairaat

2. Swalayan Alkhairaat

3. Kawasan EkonomiKhusus Alkhairaat (KEKAL)

\section{Hasil Penelitian}

Perjalanan organisasi massa Islam menimbulkan kultur baru dalam sistem social kemasyarakatan. Sehingga penampilan suatu lembaga dakwah sering diidentikkan dengan suku atau kelompok masyarakat tertentu. Di Kota Palu, organisasi Alkhairaat identik dengan orang-orang Arab dan Kaili. Organisasi As'adiyah diisi orang-orang Bugis dari kawasan Bone Soppeng Wajo Provinsi Sulawesi Selatan. Darul Dakwah wal Irsyad diisi oleh orang-orang Bugis dari jalan poros Makassar ke Pinrang, yaitu Maros, Pangkajenne Kepulauan, Barru, Pare-Pare dan Pinrang.

Polarisasi mazhab menyebabkan efek turunan yaitu lahirnya komunitas penganut suatu mazhab tertentu. Lama kelamaan, komunitas itu berkembang menjadi lembaga, organisasi, dan bahkan terbentuk sebuah negara yang mengukuhkan suatu mazhab dalam konstitusi. Penganut suatu mazhab sering menganggap aliran keagamaan yang dipilihanyaitu sebagai ajaran yang benar, sehingga menimbulkan kegamangan bagi orang-orang yang memasuki tempat ibadah yang berbeda mazhab. Organisasi Muhammadiyah memilih mengikuti 


\section{$\Delta L-\cap i 5 \mathrm{H} \exists \bar{\Delta} \mathrm{H}$, Vol. 10 No. 2, Juli-Desember 2014: 151-174}

Mazhab Maliki, sehingga sering menimbulkan pertentangan dengan Nahdlatul Ulama yang memilih Mazhab Syafi'i.

Adapun tabel perbedaan praktek ibadah antara Nahdlatul Ulama dengan Muhammadiyah, adalah sebagai berikut:

\section{Tabel I}

\section{Identitas Kelompok Dakwah ${ }^{17}$}

\begin{tabular}{|c|c|c|c|}
\hline No & Keyakinan Keagamaan & Nahdlatul Ulama & Muhammadiyah \\
\hline 1 & Bedug & Ada & tidak ada \\
\hline 2 & barzanji dan diba' & Membaca & tidak ada \\
\hline 3 & $\begin{array}{l}\text { Pembacaan pembukaan dan } \\
\text { akhir setiap kegiatan }\end{array}$ & Alfätihah & $\begin{array}{l}\text { Bismillāh dan } \\
\text { Alhamdulillāh }\end{array}$ \\
\hline 4 & $\begin{array}{l}\text { Tarhem,bacaan sebelum } \\
\text { shalat shubuh }\end{array}$ & Ada & tidak ada \\
\hline 5 & Șalawat & $\begin{array}{l}\text { Allāhumma șalli 'alā } \\
\text { sayyidinā Muhammad }\end{array}$ & tanpa sayyidinā \\
\hline 6 & Lafal salam & $\begin{array}{l}\text { Assalāmu Alaikum } \\
\text { Warahmatullāhi ta'ālā wa } \\
\text { barakātuh }\end{array}$ & tanpa ta'ala \\
\hline 7 & Tawaṣul & $\begin{array}{l}\text { Muhammad, Syekh Abdul } \\
\text { Kadir Jaelani }\end{array}$ & $\begin{array}{l}\text { tidak ada, langsung } \\
\text { tanpa perantara }\end{array}$ \\
\hline 8 & Azan shalat 5 waktu & $\begin{array}{l}\text { dimulai dengan membaca } \\
\text { Subhanalläh ... }\end{array}$ & tidak \\
\hline 9 & Azan shalat Jumat & dua kali & satu kali \\
\hline 10 & Niat wudhu & Dilafalkan & tidak dilafalkan \\
\hline 11 & Niat salta & dilafalkan & tidak dilafalkan \\
\hline 12 & Niat puasa & Dilafalkan & tidak dilafalkan \\
\hline 13 & Qunut pada shalat Subuh & Digunakan & tidak digunakan \\
\hline 14 & Jumlah rakaat shalat Tarawih & 23 rakaat & 11 rakaat \\
\hline 15 & Penentuan Ramadhan & ru'yah hilāl (lihat bulan) & hisab (menghitung) \\
\hline 16 & Penyerahan zakat & Kivi & Amil \\
\hline 17 & Harta zakat & Beras & beras, uang \\
\hline 18 & Tempat shalat ied & Masjid & Lapangan \\
\hline
\end{tabular}

${ }^{17}$ H. Abd. Latif Bustami, Kiai Politik ; Politik Kiai, (Malang: Pustaka Bayan, 2009), h. 50-52 


\begin{tabular}{|c|c|c|c|}
\hline 19 & Azan kubur, talqin & Digunakan & tidak digunakan \\
\hline 20 & Ritual kematian & $3,7,40,100,1000$ dan haul & tidak dilakukan \\
\hline 21 & Șalat Jumat bagi perempuan & tidak wajib & Boleh \\
\hline 22 & Sebutan pemuka agama & Kiai, Yayi, Romo Yai, Lora & Bapak \\
\hline 23 & $\begin{array}{l}\text { Ritual ibadah Haji di tanah } \\
\text { air }\end{array}$ & $\begin{array}{l}\text { Azan ketika berangkat, } \\
\text { ganti nama setelah pulang }\end{array}$ & tidak dilakukan \\
\hline 24 & Tongkat khațib shalat Jumat & Digunakan & tidak digunakan \\
\hline 25 & Șalawat antara dua khuțbah & Dibaca & tidak dibaca \\
\hline 26 & $\begin{array}{l}\text { Ansitu wasma'u wa atiu } \\
\text { rahimakumullāh dibaca } \\
\text { qiràah Alqurān }\end{array}$ & $\begin{array}{l}\text { setiap jeda melafalkan } \\
\text { Allah }\end{array}$ & Menyimak \\
\hline 27 & Pembacaan surah $A^{\prime} \overline{l a}^{-}$ & $\begin{array}{l}\text { Diakhiri mengucapkan } \\
\text { alaihi salām }\end{array}$ & tidak diucapkan \\
\hline 28 & $\begin{array}{l}\text { Di akhir pembacaan surah } \\
\text { Attin }\end{array}$ & $\begin{array}{l}\text { Mengucapkan bala wa ana } \\
\text { zälika minas șalihin }\end{array}$ & tidak diucapkan \\
\hline 29 & Pembacaan wirid & $\begin{array}{l}\text { bersama-sama dengan } \\
\text { suara keras }\end{array}$ & $\begin{array}{l}\text { individual, suara } \\
\text { pelan }\end{array}$ \\
\hline 30 & Istighasah & Dilakukan & tidak dilakukan \\
\hline 31 & Dasar penetapan hukum fiqh & Fatwa & Majlis Tarjih \\
\hline 32 & Dasar penetapan hukum & $\begin{array}{l}\text { Alqurān, Hadis, Ijma' dan } \\
\text { Qiyas }\end{array}$ & Alqurān, hadis \\
\hline
\end{tabular}

Hal-hal yang tertera pada tabel di atas menjadi identitas dari materi dakwah kedua rumpun organisasi keagamaan besar di Indonesia. Muballig-muballig yang berasal dari kedua organisasi itu selalu disiplin untuk menyampaikan ciri khas organisasinya sehingga ada kebanggaan korps muballig. Perbedaan dari kedua kelompok di atas dalam menyikapi setiap isu keagamaan tentunya berlandaskan dari sumber ajaran Islam. Tafsir atas dalil-dalil kegamaan selalu diidentikkan bahwa Nahdlatul Ulama berciri khas tradisional sedangkan Muhammadiyah selalu rasional.

Ideologi yang berbasis keagamaan semakin semarak dalam menampakkan wajah-wajah komunitasnya seiring dengan terciptanya mazhab-mazhab, sekte-sekte dan aliran-aliran dalam suatu agama yang resmi. Setiap komunitas pada suatu agama tertentu juga dengan membangun pandangan hidup yang dramatis dan heroik dalam rangka 


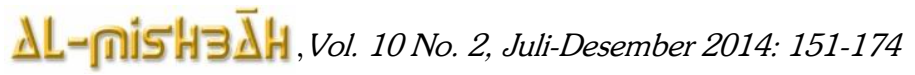

memperkuat soliditas solidaritas para pengikut mereka. Para pemimpin setiap komunitas selalu berupaya untuk terus menerus "memelihara" anggotanya, sebagai sebuah "investasi" yang menjadi "alat" tukar menukar kepentingan di tengah maraknya kompleksitas persaaingan merebut kekuasaan. Pengalaman Musda Mulia ketika menjadi Staf Ahli Menteri Agama, kerap mendapatkan laporan tentang isu ajaran sesat. Setelah diverifikasi di lapangan ternyata bukan isu aliran sesat tetapi persaingan antar tokoh yang merasa warganya direbut oleh tokoh lain ${ }^{18}$.

Kebijakan negara tentang kerukunan memang telah mengidentifikasi ada tiga kluster kerukunan yaitu kerukunan antar pemeluk agama, kerukunan internal pemeluk agama dan kerukunan antar pemeluk agama dengan pemerintah. Kerukunan internal pemeluk suatu agama, yang dalam penelitian ini adalah sesama umat Islam menjadi menarik dikaji karena berdasarkan berbagai pandangan.

Risakotta mengemukakan bahwa orang-orang yang berbeda agama justru saling memahami perbedaan pandangan di antara mereka. Justru yang seagama sering terjadi perdebatan yang tiada akhir mengenai "khilafiyah" yang terdapat dalam sebuah ajaran agama ${ }^{19}$. Dari pandangan ini dapat kita lihat misalnya, betapa Barisan Serbaguna (Banser) Gerakan Pemuda Ansor Nahdhatul Ulama yang dengan senang hati menjaga gereja pada hari-hari besar umat Nasrani. Namun, konflik berkepanjangan terjadi di Partai Kebangkitan Bangsa (PKB) yang merupakan "anak kandung politik" Nahdhatul Ulama.

Dakwah khilafiyah masih sering berkobar pada ceramahceramah di hadapan masyarakat Kota Palu. Perbedaan praktek keagamaan seperti shalat tarawih 20 rakaat dan delapan rakaat, qunut pada shalat Subuh, dan masalah bid'ah lainnya, masih sering disuguhkan di hadapan umat Islam, dengan dalih untuk memelihara

\footnotetext{
${ }^{18}$ Musda Mulia, Aku Bukan Siapa-Siapa, (Jakarta: PT Kompas Gramedia,
} 2008), h. 12 .

19 Risakotta, Memelihara Pemahaman Agama, (Makassar: UIN Alauddin, 2010), h. 3. 
solidaritas organisasi atau kelompok. Namun di sisi lain, terjadi pula pesan moderat untuk tidak menyampaikan pesan-pesan dakwah yang dapat memecah belah umat Islam.

Perkembangan organisasi massa Islam di Kota Palu, berjalan seiring dengan bertumbuhnya organisasi Islam berbasis nasional dan organisasi Islam berbasis transnasional. Organisasi tersebut adalah Alkhairāt, Muhammadiyah, Nahatul Ulama, As'adiyah, Dārul Dakwah wal Irshād (DDI), Lembaga Dakwah Islam Indonesia (LDII), Jama'ah Tabligh, Hizbut Tahrir Indonesia, Wahdah Islmiyah, Persatuan Islam (Persis), dan Hidayatullah. Afiliasi organisasi pada gerakan nasional dan transnasional, juga berkembang seiring dengan terjadinya dinamika sosial masyarakat muslim Kota Palu.

Dari berbagai organisasi massa di Kota Palu, lahirlah muballigmuballig yang dapat diklsifikasikan dalam rumpun kelompok muballig, yaitu rumpun Nahdlatul Ulama, rumpun Muhammadiyah, rumpun transnasional dan rumpun translokal. Kedua rumpun kelompok muballig terakhir disebutkan merupakan dinamika perjalanan dakwah dan menjadi ekses dari perubahan sosial. Ciri dari perubahan sosial adalah lahirnya lembaga-lembaga dalam masyarakat karena lembaga yang ada tidak mampu menampung spesialisasi dan spesifikasi yang berkembang di masyarakat.

Keberadaan NU dan Muhammadiyah yang sudah satu abad lamanya berkiprah di Indonesia, masih ada saja persoalan yang belum terakomodir oleh kedua organisasi massa itu. Mungkin dalam visi, misi dan program kerja sudah ada dan tertulis semua, namun dalam kenyataan masih ada umat yang belum tersentuh oleh pekerjaan dakwah dari NU dan Muhammadiyah. Lahirlah Partai Keadilan Sejahtera (PKS) yang memiliki model tarbiyah halaqah dengan kurikulum Ikhwanul Muslim di Mesir. Hizbut Tahrir Indonesia (HTI) yang berupaya menjalankan pesan Jamaluddin Al-Afghani "Pan Islamisme", Islam sejagad dalam satu bendera komando, mungkin seperti Tahta Suci Vatikan untuk satu komando Katolik dunia. Jamaah Tablig yang berpusat di IPB (India, Pakistan dan Banglades) untuk kerja-kerja 
dakwah militan dari mesjid ke mesjid dengan metode khurüj fi sabilillāh yang tidak dijangkau oleh para muballig NU dan Muhammadiyah.

Para muballig menunjukkan adanya "saling pengertian" antar muballig dari berbagai organisasi massa Islam. Pola tindakan komunikatif terhadap kegiatan dakwah di Kota Palu, disebabkan oleh dinamika pergulatan ekonomi (mareso masagena), fleksibilitas budaya lokal (nosampesuvu), dan kearifan tokoh masyarakat, baik formal maupun informal (tataguna).

Tindakan komunikatif (communicative action), seperti diungkapkan Habermas, tidak dapat dilepaskan dengan rasionalitas yang mendasarinya. Maka, dalam tindakan komunikatif Habermas menarik sebuah rasionalitas yang disebut rasionalitas komunikatif. Rasionalitas komunikatif ini berbeda dari rasionalitas instrumental. Tindakan komunikatif ini sungguh-sungguh rasional dan dapat dipertanggungjawabkan. ${ }^{20}$

Tindakan komunikatif mengarah pada saling pengertian (verstandingung) antara pembicara dan pendegar. Dalam tindakan bahasa, misalnya. Ucapan yang ditujukan kepada seseorang tidak hanya bersifat memerintah untuk mencapai suatu tujuan, melainkan mengambil bagian dalam proses komunikasi. Maksudnya, kalau dua orang berbicara, tindakan bicara itu berorientasi kepada saling pengertian atau kesepakatan mengenai kondisi-kondisi yang mengatur atau mengkoordinir tindakan-tindakan mereka supaya hidup bersama menjadi mungkin.

Jenis tindakan berkaitan dengan orientasinya untuk mencapai tujuan tertentu, atau untuk mencapai saling pengertian. Dalam orientasi mencapai tujuan, tindakan tersebut bersifat instrumental bila untuk situasi tindakan yang bukan bersifat sosial, sedangkan menyangkut situasi tindakan yang bersifat sosial, maka tindakan tersebut bersifat

${ }^{20}$ Joao Piedade Inocencio, "Proses Dialog Interaksi" dalam Budi Susanto, Teologi dan Praksis Komunikasi Post-modern, (Yogyakarta: Kanisius, 1994), h. 110. 
strategis. Tindakan komunikatif berada dalam situasi tindakan yang bersifat sosial.

\section{Penutup}

Adapun kesimpulan dalam penelitian ini adalah:

1. Pola pemahaman keislaman muballig di Kota Palu berdasarkan jenjang pendidikan, baik formal maupun informal, di bawah naungan sebuah organisasi massa. Dalam praktek dakwah, muballig menegaskan aliran mazhab yang dianut oleh organisasinya dalam rangka menguatkan solidaritas kelompok. Sedangkan ketika berdakwah di jamaah organisasi lain, pola dakwah moderat selalu dikumandangkan demi terciptanya ukhuwah Islamiyah.

2. Penyampaian materi dakwah yang mengandung unsur khilafiyah, disampaikan oleh muballig di Kota Palu dengan menerangkan pijakan aliran mazhab berdasarkan Alqurān dan Hadis. Muballig meyakini bahwa sarana informasi tentang masalah khilafiyah, menyebabkan umat Islam di Kota Palu dapat memahami dan menerimanya.

\section{Daftar Pustaka}

Abd al-Baqi, Muhammad Fuad, Mu'jam Almufahraz Li Alfaz Alqurān Alkarim. Beirut: Dar al-Fikr, 1985).

Biro Pusat Statistik Provinsi Sulawesi Tengah, 2013

Bungin, Burhan, Konstruksi Sosial Media, (Jakarta: Media Pers, 2001).

Bustami, H. Abd. Latif, Kiai Politik ; Politik Kiai, (Malang: Pustaka Bayan, 2009).

Eilers, F. Josef, Berkomunikasi Antara Budaya, (Flores: Nusa Indah, 1995).

Harfeni. Sejarah Dakwah. (Jakarta: Rajawali Pers, 2005).

Inocencio, Joao Piedade "Proses Dialog Interaksi" dalam Budi Susanto, Teologi dan Praksis Komunikasi Post-modern, (Yogyakarta:

Kanisius, 1994). 
Khaldun, Ibnu, Muqaddimah, (Jakarta: Pustaka: Pustaka Firdaus, 1986)

Kuswarno, Engkus, Metode Penelitian Fenomenologi, (Bandung: Widya Pajajaran, 2008).

Kymlicka, Kewargaan Multikultural. (Jakarta. Pustaka LP3ES, 2002).

Mathar, Qasim, "Demokrasi dan Kebebasan Beragama Pada Masyarakat Multikultural", dalam Syihabuddin (ed.), Memelihara Kerukunan Melalui Pendidikan Multikultural, (Jakarta: Kementerian Koordinator Kesejahteraan Rakyat, 2009).

Mulia, Musda, Aku Bukan Siapa-Siapa, (Jakarta: PT Kompas Gramedia, 2008).

Mulyana, Deddy, Komunikasi Antar Budaya, (Bandung: Remaja Rosdakarya, 2000).

Risakotta, Memelihara Pemahaman Agama, (Makassar: UIN Alauddin, 2010).

Sutarno. Pendidikan Multikultural. (Jakarta: Departemen Pendidikan Nasional, 2008).

www.wikipedia.com, 28 Mei 2014 